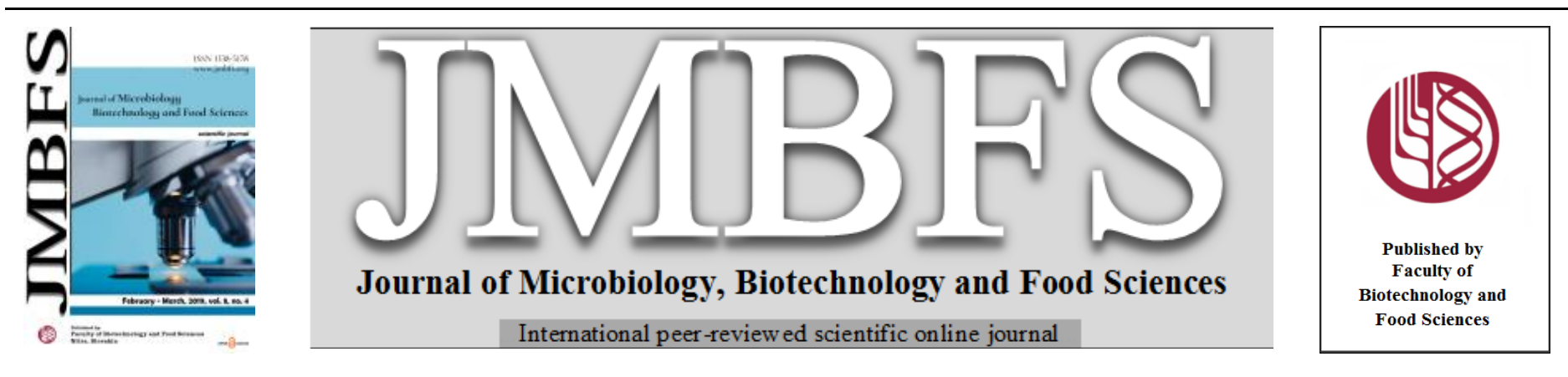

\title{
THE EFFECT OF INCREASING DOSES OF FOLIAR APPLIED REGULATORS OF POLYAMINE BIOSYNTHESIS IN MIXTURE WITH TRIAZINE HERBICIDE ON FORMATION OF SPRING BARLEY BIOMASS
}

\author{
Pavol Trebichalský, Daniel Bajčan, Luboš Harangozo, Tomáš Tóth, Radovan Stanovič \\ Address(es): Ing, PhD., Pavol Trebichalský, \\ Faculty of Biotechnology and Food Sciences, Department of Chemistry, Slovak University of Agriculture, Tr. A. Hlinku 2, 949 76, Nitra, Slovak Republic, tel. \\ $+42137 / 6415376$.
}

*Corresponding author: pavol.trebichalsky@uniag.sk

doi: $10.15414 / j m b f s .2019 .8 .4 .995-998$

\section{ARTICLE INFO}

Received 8. 6. 2018

Revised 28. 9. 2018

Accepted 25. 10. 2018

Published 1. 2. 2019

Regular article OPEN OACCESS $_{\text {A }}$

\begin{abstract}
The use of herbicides has become a potential tool in modern agriculture to get rid of weeds menace, but unknowingly the indiscriminate application of herbicides has resulted in adverse effects on the morphological, physiological and biochemical characteristics of crop plants. Herbicide effect of triazine herbicide (solo applied, or in combinations with regulators of polyamine biosynthesis: $\gamma$ aminobutyric acid, propylenediamine and salicyl acid) and quantitative parameters of spring barley (variety Kompakt) was evaluated under simulative conditions of hydroponic experiments under light platform. The experiment was carried out in hydroponics under light platform with linear fluorescent lamp at Department of chemistry SUA Nitra, where 9 pots was used with 24 barley grains/per pot of variety Kompakt and 5.5 litres of mineral solution, which were prepared from stock solutions containing optimal content of macroelements (K, P, N, Ca, Mg) and micro-elements (B, Mn, Cl, Zn, S, Cu, Mo, Fe) for plants. At hydroponic experiment short-time negative effect of triazine herbicide at formation of biomass and root system and more significant negative influence at the amount of formed fresh biomass and root system were observed. Our experiments after foliar treatment of barley plants with herbicide confirm minimal short-time negative effect of mentioned herbicide. It indicates lowering of the amount of retained water in roots. Regulators of polyamine biosynthesis in hydroponics reduced inhibitory effect of tested pesticide on formation of organic matter, while their influence was manifested on amount of produced fresh biomass and root matter than on amount of dry matter. The most suitable doses of 100

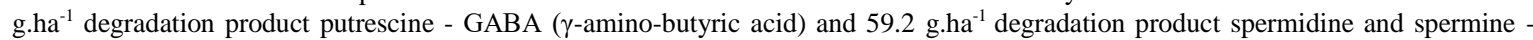
DAP (1,3- propylendiamine) were used on elimination of negative effects of triazine herbicide in barley.
\end{abstract}

\section{INTRODUCTION}

Since plants were first domesticated $\sim 10,000$ years ago, crop plants have been exposed to recurrent infestations by weed plants (Frenkel $\boldsymbol{e t}$ al., 2017). To date, weeds are the most important biotic factor affecting agriculture production and causing yield losses in various crops worldwide [e.g., Corylus avellana (KayaAltop et al., 2016), Zea mays (Soltani et al., 2016) and Oryza sativa (Chauhan and Johnson, 2011; Chauhan and Opena, 2012)]. Strategies for weed control are based primarily on chemical control, since the last decades the use of synthetic chemical products has been dramatically increased (Sandín-España, 2011).

The principle mode of action of triazine herbicides is the inhibition of photosynthesis. The triazines were shown to inhibit PSII but have no effect on PSI (Trebst, 2008). Triazines and phenylureas shut down the photosynthetic process in susceptible plants by binding to specific sites within the plants photosystem II (PS II) complex. A number of commercially available herbicides, including triazines (simazine) and derivatives of urea (linuron) inhibit photosynthetic electron flow via a direct interaction with the Qb-protein (Kortekamp, 2011).

Polyamines are low molecular weight organic polycations,v positively charged at physiological $\mathrm{pH}$, that are present in a wide range of living organisms. In plants, polyamines are involved in different physiological processes, such as growth, development, and response to abiotic and biotic stresses (Tiburcio et al., 2014). The diamine putrescine, the triamine spermidine and the tetramine spermine are the main polyamines found in higher organisms (Montilla-Bascón, 2016).

Several genes involved in polyamine biosynthetic pathways have so far been already reported to be upregulated when exposed to one or combination of one or more abiotic stresses. Putrescine is the first polyamine that is accumulated in cells on exposure to abiotic stress. Interestingly, increase in putrescine concentration leads to the induction of enzymes that are responsible for the conversion of putrescine to spermidine and spermine, through auto-regulation process. Concentration of putrescine, spermidine, and spermine varies greatly within the cell mostly because of the simultaneous degradation pathway which occurs within the cell, whereby generating $\mathrm{H}_{2} \mathrm{O}_{2}$ (Gupta et al., 2016). Abiotic and biotic stresses cause alterations in the normal physiological processes of all plants, including the economically important crops. Plant damage and decrease in their productivity take place most often due to naturally occurring unfavorable factors of the environment (Todorova et al, 2013). Polyamines (putrescine, spermidine and spermine) are also known to participate in plants for protection against abiotic stress conditions (Groppa and Benavides, 2007). Spermidine offered protection against paraquat toxicity in Raphanus sativus seedlings (Varshney et al., 2015; Kim and Jin, 2006). Diethylenetriamine polyamine increased the protection against 2, 4-D herbicide in the triticale plants. Application of polyamines significantly prevented the loss of chlorophyll content, reduced the lipid peroxidation caused by diuron herbicide in leaves of Zea mays and also increased the activity of SOD, GPX and GR (Durmus and Kadioğlu, 2005a). In plants, 1,3-diaminopropane (DAP) is co-produced with $\mathrm{H}_{2} \mathrm{O}_{2}$ from metabolism of the classical polyamines. While $\mathrm{H}_{2} \mathrm{O}_{2}$ is a labile signaling radical in many biotic and abiotic stress responses, DAP had only been qualified as a "rare" polycation with no clear biological functions (Cona et al., 2006; Jammes, 2014). One estimated concentration in dry tissues from unstressed Arabidopsis is approximately $4 \mathrm{pmol} . \mathrm{mg}^{-1}$. The concentration of DAP vary according to those of the common polyamines, which are detected prefentially in stressed tissues (Takahashi and Kakehi, 2010). $\gamma$-aminobutyric acid (GABA), a non-protein amino acid, has attracted significant attention within the past decade, mainly due to its diverse physiological implications in plants, animals, as well as microorganisms (Nikmaram et al., 2017). In plants, GABA constitutes a considerable portion in the free amino acids pool. GABA is synthesized from 2oxoglutarate and degraded into succinate by the so-called GABA shunt, bypassing the citric acid cycle enzymes. GABA is accumulated under several biotic and abiotic stress conditions in plants (Sánchez-López et al., 2016), although the functional relationship between GABA accumulation and stress remains poorly understood (Poojary et al., 2017).

The concentrations of polyamines are controlled by a dynamic balance between biosynthesis and catabolism. Polyamine biosynthetic pathways are well 
established in plants (Knott et al., 2007, Kakehi et al., 2010, Alcázar et al., 2010, Mattoo et al., 2010, Liu et al., 2014).

Our work was aimed at herbicide effect of triazine herbicide (applied singly, or in combination with regulators of polyamine biosynthesis) on development of spring barley (variety Kompakt) under simulative conditions of hydroponic experiments under light platform.

\section{MATERIAL AND METHODS}

Experiment was carried out under hydroponic conditions (under light platform with linear fluorescent lamp with power wattage $28 \mathrm{~W}$ and colour rendering index 80 (neutral white)) at Department of chemistry SUA Nitra, where 9 pots (while harvesting the matter from each pot of variant four repetitions were done by dividing of pot area) with 24 seeds/per pot variety Kompakt and 5 litres of mineral solution which was prepared from solutions: $\mathrm{KH}_{2} \mathrm{PO}_{4}\left(6,8\right.$ g.l $\left.{ }^{-1}\right), \mathrm{KNO}$ $\left(50,5 \mathrm{~g} . \mathrm{l}^{-1}\right), \mathrm{Ca}\left(\mathrm{NO}_{3}\right)_{2} \cdot 4 \mathrm{H}_{2} \mathrm{O}\left(118,1 \mathrm{~g} . \mathrm{l}^{-1}\right)$ and $\mathrm{MgSO}_{4} \cdot 7 \mathrm{H}_{2} \mathrm{O}\left(49,2 \mathrm{~g} . \mathrm{l}^{-1}\right)$. From each of solutions $12.5 \mathrm{ml}$ was pipetted into 5 litres flask. Another solution containing available ferrous ions (complex bind to Chelaton 2) by dissolving of $5.4 \mathrm{~g} \mathrm{FeCl}_{3}$ in $200 \mathrm{ml}$ distilled water in one flask and in second one $7.4 \mathrm{~g}$ of Chelaton 2 (EDTA) in $200 \mathrm{ml}$ distilled water was dissolved. Mentioned solutions after preparation were blended and from this solution $8 \mathrm{ml}$ was pipetted into 51 of mineral solution. It is necessary that the mineral solution should contain also microelements, thus another solutions were prepared by blending of $1,4 \mathrm{~g} . \mathrm{l}^{-1}$ $\mathrm{H}_{3} \mathrm{BO}_{3}, 0,9$ g. $.^{-1} \quad \mathrm{MnCl}_{2} \cdot 4 \mathrm{H}_{2} \mathrm{O}, 0,11$ g. $.^{-1} \quad \mathrm{ZnSO}_{4} .7 \mathrm{H}_{2} \mathrm{O}, 0,04$ g..$^{-1} \quad \mathrm{CuSO}_{4} .5 \mathrm{H}_{2} \mathrm{O}$ and 0,05 g. $1^{-1}\left(\mathrm{NH}_{4}\right)_{6} \mathrm{Mo}_{7} \mathrm{O}_{24} .4 \mathrm{H}_{2} \mathrm{O}$ in distilled water. From these solutions $2,5 \mathrm{~m}$ into $500 \mathrm{ml}$ flask was pipetted and made up with distilled water to the mark. Afterwards $12,5 \mathrm{ml}$ of such prepared solution was pipetted into 51 of mineral solution. Final pH was adjusted to value 5,5 (with sodium hydroxide, or with hydrochloric acid).

After forming of 2-3 leaves (the height of aboveground biomass of barley plants was $15-20 \mathrm{~cm}$ ) foliar treatment was carried out according to Table 1 . Triazine herbicide with its main and effective compound cyanazine and its formula 2-(4-

chloro-6-ethylamino-1,3,5-triazin-2-ylamino)-2-methylpropiono-nitrile, was singly foliar applied in experiments or applied in combination with regulators of polyamine biosynthesis. PDA - propylendiamine of dihydrochloride, p.a (producer: Sigma - Aldrich, Germany) GABA - $\gamma$-aminobutyric acid, p.a (Producer: Sigma - Aldrich, Germany) KS - salicylic acid p.a. (Lachema a.s., Brno, Czech republic). After 20 days the hydroponic experiment was ended, plants of barley were analyzed: weights of fresh as well as dry aboveground parts also root matters of barley were gained.

Results were evaluated by statistical program Statgraphics 4.0 (Statpoint Technologies, Inc., Czech Republic), the data were analyzed by means of oneway analysis of variance (ANOVA).

Table 1 Variants of the hydroponic experiment

\begin{tabular}{|c|c|}
\hline $\begin{array}{l}\text { VARIANT } \\
\text { NUMBER }\end{array}$ & FOLIAR TREATMENT \\
\hline 1 & $\begin{array}{l}\text { Control: } \\
6.4 \mathrm{ml} \text { water }\end{array}$ \\
\hline 2 & $\begin{array}{c}\text { Triazine herbicide } 0.51^{2} \mathrm{ha}^{-1}: \\
0.25 \mathrm{ml} \text { water solution of triazine herbicide }+6.20 \mathrm{ml} \text { water }\end{array}$ \\
\hline 3 & $\begin{array}{l}\text { Triazine herbicide } 0.5 \text { l.ha }^{-1}+\text { GABA } 500 \mathrm{~g}^{-h^{-1}}: \\
0.25 \mathrm{ml} \text { water solution of triazine herbicide }+1.25 \mathrm{ml} 20 \\
\text { mM solution GABA }+4.90 \mathrm{ml} \text { water }\end{array}$ \\
\hline 4 & $\begin{array}{c}\text { Triazine herbicide } 0.5 \text { l.ha }^{-1}+\text { GABA } 100 \mathrm{~g}^{-h^{-1}} \text { : } \\
0.25 \mathrm{ml} \text { water solution of triazine herbicide }+0.25 \mathrm{ml} 20 \\
\text { mM solution GABA + 5.90 ml water }\end{array}$ \\
\hline 5 & $\begin{array}{c}\text { Triazine herbicide } 0.5 \text { l.ha }^{-1}+\text { GABA } 10{\mathrm{~g} . h a^{-1}}^{\prime} \\
0.25 \mathrm{ml} \text { water solution of triazine herbicide }+25.0 \mu \mathrm{l} 20 \\
\mathrm{mM} \text { solution GABA }+6.15 \mathrm{ml} \text { water }\end{array}$ \\
\hline 6 & $\begin{array}{l}\text { Triazine herbicide } 0.5 \text { l.ha }{ }^{-1}+\text { DAP } 59.2{\mathrm{~g} . h a^{-1}:}^{-} \\
0.25 \mathrm{ml} \text { water solution of triazine herbicide }+1.00 \mathrm{ml} 2 \\
\text { mM solution DAP }+5.20 \mathrm{ml} \text { water }\end{array}$ \\
\hline 7 & $\begin{array}{c}\text { Triazine herbicide } 0.5 \text { l.ha }^{-1}+\text { DAP } 10 \text { g.ha }^{-1}: \\
0.25 \mathrm{ml} \text { water solution of triazine herbicide }+166.0 \mu 12 \\
\text { mM solution DAP + 6.00 ml water }\end{array}$ \\
\hline 8 & 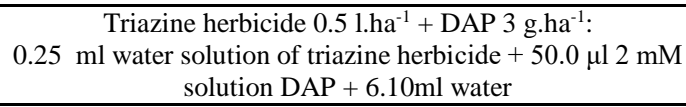 \\
\hline 9 & $\begin{array}{c}\text { Triazine herbicide } 0.25 \text { l.ha }^{-1}+\text { salicylic acid } 50 \mathrm{~g}^{-h^{-1}} \text { : } \\
0.25 \mathrm{ml} \text { water solution of triazine herbicide }+1.00 \mathrm{ml} 2.5 \\
\mathrm{mM} \text { solution of salicylic acid }+5.15 \mathrm{ml} \text { water }\end{array}$ \\
\hline
\end{tabular}

\section{RESULTS AND DISCUSSION}

Cereals are grown across the globe for several thousand years, and after all these years have been subjected to various exogenous and endogenous factors which have formed their respective genomes. Barley (Hordeum vulgare, L.) is economically important crops mainly for food production and malting, but the value is increased due to use as a functional food with a variety of health benefits (Hua et al., 2015; Tomka et al., 2017).

The toxicity of herbicides has been affected by an amount of an applied dose, because very low doses of these compounds could have positive effects (it means that they can act as growth regulators). At low doses, triazine herbicides stimulate growth through beneficial effects on nitrogen metabolism and through auxin-like effects. Thus, sublethal doses of several herbicides have applications other than weed control (Veliny et al., 2010). Also the results of Cedergreen (2008) show that the globally most widely used herbicide, glyphosate, together with the sulfonylurea, metsulfuron-methyl, can induce a real stimulation in biomass growth of approximately $25 \%$ when applied at doses corresponding to $5-10 \%$ field rate.

Our experiments after foliar treatment of barley plants (variety Kompakt) with triazine herbicide or its mixture with regulators of polyamine biosyntesis confirm minimal short-lasting 8-days negative effect of mentioned herbicide on formation of upper biomass and root system. More obvious negative effect has triazine herbicide on amount of gained fresh biomass and root system. The application of this herbicide in hydroponic experiment in comparison to control variant statistically non-significantly reduced the formation of fresh biomass by $19.6 \%$ (Table 2) statistically significant the formation of fresh root system even by $87.6 \%$ (Table 3), in case of dry matter of biomass and root system was statistically non-significant decline of weight approx. by $10 \%$. Herbicide has reduced dramatically the amount of water in roots (its amount in fresh matter was only $38.06 \%$ ), what is connected with reversible changes in their functionality (Table 3). Jones et al. (2013) had carried out experiments to test herbicide effects of indaziflam (35 and $\left.52.5 \mathrm{~g} \mathrm{ha}^{-1}\right)$, prodiamine $\left(0.84 \mathrm{~kg} \mathrm{ha}^{-1}\right)$, oxadiazon $(3.36 \mathrm{~kg}$ $\left.\mathrm{ha}^{-1}\right)$, and isoxaben $\left(1.12 \mathrm{~kg} \mathrm{ha}^{-1}\right)$ applications in hydroponic culture on hybric bermudagrass [C. dactylon (L.) Pers. x C. transvaalensis Burtt-Davy] tissue nutrient content. Prodiamine, indaziflam, and isoxaben reduced visual root mass relative to non-treated plants. Consequently, these herbicides reduced phosphorus $(\mathrm{P})$, sulfur $(\mathrm{S})$, and potassium $(\mathrm{K})$ content in turf foliar tissue. Treatment with indaziflam reduced magnesium $(\mathrm{Mg})$ and manganese $(\mathrm{Mn})$ content in turf foliar tissue compared to non-treated plants.

Hydroponics has its important place in phytoremediation. Guimarães $\boldsymbol{e t}$ al. (2011) carried out the experiment where plants of macrophytes Azolla caroliniana, Salvinia minima, and Lemna gibba were put in mineral hydroponic solution, and triazine herbicide atrazine was applied in following amounts 0 ; $0.01 ; 0.1 ; 1.0 ; 10.0 \mathrm{mg} . \mathrm{l}^{-1}$. Authors found out that the decrease in biomass accumulation was observed in the all macrophytes, as well as toxic effects evidenced by the symptomatology developed by the plants which caused their deaths. The chlorosis and necrosis allowed to observe in the plants the high sensitivity of the three species to the herbicide.

Applied regulators of polyamine biosynthesis in optimal amounts not only eliminate negative effect of used pesticide, when there is more obvious effect in weight of fresh biomass and root system in comparison to dry matter, but also in optimal amount in mixture with herbicide they act stimulative (in comparison to control, with water treated plants). Common application of herbicide with regulators of polyamine biosynthesis acted positively only on fresh matters of barley plants (except of salicylic acid), in case of upper biomass this combination of applied compounds (Table 2) enhanced its weigh by 5.2-84.6\% (statistically significant only after application of herbicide with $\mathrm{GABA}_{500}$ ) and in case of fresh root system an increase by $93,7-663,5 \%$ was observed (statistical significant after application of herbicide with $\mathrm{GABA}_{100}$, or with higher doses of DAP) in comparison to the plants of barley treated only by the herbicide (Table 3). Increase of weight of dry matter was influenced by positive effect of regulators of polyamine biosynthesis (except of high doses of GABA and salicylic acid), i.e. by 19.1-68.1\% (statistically significant was the combination of herbicide and $\mathrm{GABA}_{100}$ ) in upper biomass and in root system statistically nonsignificant by $7.6-41.8 \%$. From this point of view the most suitable applications

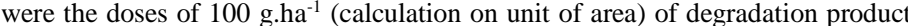
of putrescine - GABA ( $\gamma$-aminobutyric acid) and $59.2 \mathrm{~g}^{-h^{-1}}{ }^{-1}$ degradation product spermidine and spermine - DAP (1,3- propylendiamine).

Similar effects of polyamines spermine and putrescine against effects of herbicide used in agriculture paraquat (inductor of oxidative stress) was documented also Durmus and Kadioğlu (2005b) in leaves of maize (Zea mays) Leaves of these plants were pre-treated by spermine and putrescíne at concentration $1 \mathrm{mM}$ and afterwards these tissues of plants were treated by paraquat. Durmus and Kadioğlu (2005b) found out that pretreatment with 1 $\mathrm{mM}$ of spermine and putrescine significantly prevented the losses in chlorophyll and carotenoid levels induced by paraquat. Ascorbic acid content in the leaves pretreated with both polyamines was found to be higher than those of the leaves pretreated with water. Authors also reported that pretreatment with spermine and putrescine was determined to have some effects on the activities of superoxide dismutase (SOD) and peroxidase (POD). $1 \mathrm{mM}$ of spermine increased SOD activity, but putrescine has no significant effect on SOD activity. On the other hand, POD activity was recorded to increase slightly in response to both concentrations of spermine and $1 \mathrm{mM}$ of putrescine. The results showed that such polyamine pretreated plants may become more tolerant to oxidative stress due to increases in the antioxidative enzymes and antioxidants. The same results were published also by Fariduddin et al. (2013), who refer that pretreatment with 
spermidine and spermine offered higher levels of endogenous spermidine and spermine which was able to reduce paraquat toxicity (30\%) possibly due to increased activities of catalase and peroxidase in the potato plants (Solanum tuberosum).

Polyamines have the function to eliminate not only the herbicide stress, but also to inhibit other unfavourable factors, such as frost or excessive salinization. Todorova, Sergiev and Alexieva (2011) had grown winter wheat cultivars under common conditions of growth. Two-week old seedlings of winter wheat were exposed to $4^{\circ} \mathrm{C}$ during 6 hours and then they were transferred into the dark by $12^{\circ} \mathrm{C}$ during 24 hours. Twenty-four hours before freezing stress, some of the plants were sprayed by researchers with aqueous solutions of spermine, spermidine, putrescine, 1,3-diaminopropane (1,3-DAP) and diethylenetriamine
(DETA). The research data showed that freezing stress caused a decrease in the fresh weight, chlorophyll content and plant survival rate, accompanied by a simultaneous accumulation of free proline and the enhanced leakage of electrolytes. Preliminary treatment with polyamines caused a decline in electrolyte leakage and a considerable augmentation in proline quantity, indicating that the compounds are capable of preventing frost injury. Additionally, the foliar application of polyamines retarded the destruction of chlorophyll, and lessened fresh weight losses due to freezing stress. The application of polyamines to wheat crops could be a promising approach for improving plant growth under unfavourable growth conditions, including freezing temperatures

$\underline{\text { Table } 2 \text { Parameters of overground matter in hydroponic experiment }}$

\begin{tabular}{|c|c|c|c|c|c|}
\hline \multirow{2}{*}{ Treatment } & \multicolumn{4}{|c|}{ Overground matter } & \multirow{2}{*}{$\%$ of water } \\
\hline & fresh $(g)$ & $\%$ to herbicide & dry (g) & $\%$ to herbicide & \\
\hline $\begin{array}{l}\text { Control, } \\
\text { water }\end{array}$ & $51.13^{\mathrm{A}}$ & 119.6 & $7.14^{\mathrm{A}}$ & 111.6 & 86.06 \\
\hline $\begin{array}{l}\text { Herbicide } \\
\qquad\left(0.5 \mathrm{dm}^{-3} \cdot \mathrm{ha}^{-1}\right)\end{array}$ & $42.74^{\mathrm{A}}$ & 100.0 & $6.40^{\mathrm{A}}$ & 100.0 & 85.03 \\
\hline $\begin{array}{l}\text { Herbicide } \\
\left(0.5 \mathrm{dm}^{-3} \cdot \mathrm{ha}^{-1}\right)+\mathrm{GABA}_{500}\end{array}$ & $44.96^{\mathrm{B}}$ & 105.2 & $6.14^{\mathrm{B}}$ & 95.9 & 86.34 \\
\hline $\begin{array}{l}\text { Herbicide } \\
\left(0.5 \mathrm{dm}^{-3} \cdot \mathrm{ha}^{-1}\right)+\mathrm{GABA}_{100}\end{array}$ & $78.89^{\mathrm{A}}$ & 184.6 & $10.76^{\mathrm{A}}$ & 168.1 & 86.36 \\
\hline $\begin{array}{l}\text { Herbicide } \\
\left(0.5 \mathrm{dm}^{-3} \cdot \mathrm{ha}^{-1}\right)+\mathrm{GABA}_{10}\end{array}$ & $66.24^{\mathrm{A}}$ & 155.0 & $9.16^{\mathrm{B}}$ & 148.1 & 86.17 \\
\hline $\begin{array}{l}\text { Herbicide } \\
\left(0.5 \mathrm{dm}^{-3} \cdot \mathrm{ha}^{-1}\right)+\mathrm{PDA}_{59.2}\end{array}$ & $57.99^{\mathrm{A}}$ & 135.7 & $9.20^{\mathrm{AB}}$ & 143.8 & 84.14 \\
\hline $\begin{array}{l}\text { Herbicide } \\
\left(0.5 \mathrm{dm}^{-3} \cdot \mathrm{ha}^{-1}\right)+\mathrm{PDA}_{10}\end{array}$ & $51.95^{\mathrm{A}}$ & 121.5 & $7.64^{\mathrm{A}}$ & 119.4 & 85.29 \\
\hline $\begin{array}{l}\text { Herbicide } \\
\left(0.5 \mathrm{dm}^{-3} \cdot \mathrm{ha}^{-1}\right)+\mathrm{PDA}_{3}\end{array}$ & $55.22^{\mathrm{A}}$ & 129.2 & $7.62^{\mathrm{AB}}$ & 119.1 & 86.20 \\
\hline Herbicide $+\mathrm{KS}_{50}$ & $32.42^{\mathrm{A}}$ & 75.9 & $4.33^{\mathrm{A}}$ & 67.7 & 86.64 \\
\hline
\end{tabular}

NOTE: Letters in table stand for statistical significance in columns $(p<0.05)$. Their conformity means that the values are statistically non-significant and different letters characterize statistically significance

Table 3 Parameters of root matter in hydroponic experiment

\begin{tabular}{|c|c|c|c|c|c|}
\hline \multirow[b]{2}{*}{ Treatment } & \multicolumn{4}{|c|}{ Weight of root } & \multirow[b]{2}{*}{$\%$ of water } \\
\hline & fresh $(\mathrm{g})$ & $\%$ to herbicide & dry (g) & $\%$ to herbicide & \\
\hline $\begin{array}{l}\text { Control, } \\
\text { water }\end{array}$ & $8.33^{\mathrm{B}}$ & 187.6 & $3.00^{\mathrm{B}}$ & 109.1 & 63.99 \\
\hline $\begin{array}{l}\text { Herbicide } \\
\quad\left(0.5 \mathrm{dm}^{-3} \cdot \mathrm{ha}^{-1}\right)\end{array}$ & $4.44^{\mathrm{A}}$ & 100.0 & $2.75^{\mathrm{AB}}$ & 100.0 & 38.06 \\
\hline $\begin{array}{l}\text { Herbicide } \\
\left(0.5 \mathrm{dm}^{-3} \cdot \mathrm{ha}^{-1}\right)+\mathrm{GABA}_{500}\end{array}$ & $8.60^{\mathrm{AB}}$ & 193.7 & $2.30^{\mathrm{A}}$ & 83.6 & 73.26 \\
\hline $\begin{array}{l}\text { Herbicide } \\
\left(0.5 \mathrm{dm}^{-3} \cdot \mathrm{ha}^{-1}\right)+\mathrm{GABA}_{100}\end{array}$ & $33.90^{\mathrm{B}}$ & 763.5 & $3.90^{\mathrm{B}}$ & 141.8 & 88.50 \\
\hline $\begin{array}{l}\text { Herbicide } \\
\left(0.5 \mathrm{dm}^{-3} \cdot \mathrm{ha}^{-1}\right)+\mathrm{GABA}_{10}\end{array}$ & $25.65^{\mathrm{A}}$ & 577.7 & $3.67^{\mathrm{AB}}$ & 133.5 & 85.69 \\
\hline $\begin{array}{l}\text { Herbicide } \\
\left(0.5 \mathrm{dm}^{-3} \cdot \mathrm{ha}^{-1}\right)+\mathrm{PDA}_{59.2}\end{array}$ & $12.01^{\mathrm{B}}$ & 270.5 & $3.72^{\mathrm{B}}$ & 135.3 & 69.03 \\
\hline $\begin{array}{l}\text { Herbicide } \\
\left(0.5 \mathrm{dm}^{-3} \cdot \mathrm{ha}^{-1}\right)+\mathrm{PDA}_{10}\end{array}$ & $21.50^{\mathrm{B}}$ & 484.2 & $2.96^{\mathrm{A}}$ & 107.6 & 86.23 \\
\hline $\begin{array}{l}\text { Herbicide } \\
\left(0.5 \mathrm{dm}^{-3} \cdot \mathrm{ha}^{-1}\right)+\mathrm{PDA}_{3}\end{array}$ & $20.62^{\mathrm{A}}$ & 464.4 & $2.99^{\mathrm{A}}$ & 108.7 & 85.50 \\
\hline Herbicide $+\mathrm{KS}_{50}$ & $4.16^{\mathrm{A}}$ & 93.7 & $1.67^{\mathrm{A}}$ & 60.7 & 59.86 \\
\hline
\end{tabular}

NOTE: Letters in table stand for statistical significance in columns $(p<0.05)$. Their conformity means that the values are statistically non-significant and different letters characterize statistically significance

\section{CONCLUSION}

Short-time lasting negative effect of triazine herbicide on formation of biomass and root system and more significant negative effect on amount of formed fresh and also root system were observed in hydroponic experiment. Our experiments after foliar treatment of barley plants (variety Kompakt) with herbicide confirm minimal short-time lasting negative effect of this herbicide. It indicates lowering of amount of retained water in roots. Regulators of polyamine biosynthesis in hydroponics declined inhibitory effect of tested pesticide on formation of organic matter, while their effect was manifested more significant at the amount of produced fresh biomass and root matter than on amount of dry matter. It could be summarized that at optimal amount the regulators of polyamine biosynthesis $(\gamma-$ aminobutyric acid and 1,3-diaminopropane) in mixture with herbicide act shorttime stimulating on quantity of matter formation of barley plants. Regulators of polyamine biosynthesis have positive influence not only on reduction of herbicide stress, but they also inhibit also other stress factors (caused e.g. by temperature extremes, by excessive salinity, UV-radiation, or by toxic elements and compounds).

Acknowledgement: The work was supported by grants KEGA 015SPU-4/2016. 


\section{REFERENCES}

ALCÁZAR, R., ALTABELLA, T., MARCO, F., BORTOLOTTI, C., REYMOND, M., KONCZ, C. 2010. Polyamines: molecules with regulatory functions in plant abiotic stress tolerance. Planta, 231(6), 1237 1249. https://doi.org/10.1007/s00425-010-1130-0.

CEDERGREEN, N. 2008. Herbicides can stimulate plant growth. Weed Research, 48, 429-438. https://doi.org/10.1111/j.1365-3180.2008.00646.x CONA, A., REA, G., ANGELINI, R., FEDERICO, R., TAVLADORAKI, P. 2006. Functions of amine oxidases in plant development and defence. Trends in Plant Science, 11(2), 80-88. https://doi.org/10.1016/j.tplants.2005.12.009.

DURMUS, N., KADIOĞLU, A. 2005a. Reduction of paraquat toxicity in maize leaves by benzyladenine. Acta Biologica Hungarica, 56(1-2), 97-107.

https://doi.org/10.1556/abiol.56.2005.1-2.10.

DURMUS, N. KADIOĞLU, A. 2005b. Spermine and putrescine enhance oxidative stress tolerance in maize leaves. Acta Physiologiae Plantarum 27(4), 515-522. https://doi.org/10.1007/s11738-005-0057-8.

FARIDUDDIN, Q., VARSHNEY, P. YUSUF, M. AHMAD, A. 2013 Polyamines: potent modulators of plant responses to stress. Journal of Plant Interactions, 8(1), 1-16. https://doi.org/10.1080/17429145.2012.716455.

FRENKEL, E., MATZRAFI, M., RUBIN, B., PELEG Z. 2017. Effects of Environmental Conditions on the Fitness Penalty in Herbicide Resistant Brachypodium hybridum, Frontiers in Plant Science, https://doi.org/10.3389/fpls.2017.00094

GROPPA, M.D., BENAVIDES, M.P. 2007. Polyamines and abiotic stress: recent advances. Amino acids, 34(1), 35-45. https://doi.org/10.1007/s00726-007-0501-8 GUIMARÃES, F.P., AGUIAR, R., KARAM, D., OLIVEIRA, J.A., SILVA, J.A.A., SANTOS, C.L., SANT'ANNA-SANTOS, B.F., LIZIERI-SANTOS, C. 2011. Potential of macrophytes for removing atrazine from aqueous solution. Planta daninha, 29 (special nomer), 1137-1147. https://doi.org/10.1614/ws-d09-00028.1

GUPTA, K., SENGUPTA, A., CHAKRABORTY, M., GUPTA, B. 2016 Hydrogen peroxide and polyamines act as double edged swords in plant abiotic stress responses. Frontiers in Plant Science, 7, 1343. https://doi.org/10.3389/fpls.2016.01343

HUA, W., ZHANG, X., ZHU, J., SHANG, Y., WANG, J., JIA, Q., LI, CH., \& YANG, J. 2015. A study of genetic diversity of colored barley (Hordeum vulgare L.) using SSR markers. Genetic Resources and Crop Evolution, 62 (3), 395-406. https://doi.org/10.1007/s10722-014-0165-7

CHAUHAN B. S., OPENA J. 2012. Effect of tillage systems and herbicides on weed emergence, weed growth, and grain yield in dry-seeded rice systems. Field Crops Research. 137, 56-69. https://doi.org/10.1016/j.fcr.2012.08.016

CHAUHAN B. S., JOHNSON D. E. 2011. Growth response of direct-seeded rice to oxadiazon and bispyribac-sodium in aerobic and saturated Soils. Weed Science. 59(1), 119-122. https://doi.org/10.1614/ws-d-10-00075.1

JAMMES, F., LEONHARDT, N., TRAN, D., BOUSSEROUEL, H., VÉRY, A.A., RENOU, J.-P., VAVASSEUR, A., KWAK, J.M., SENTENAC, H., BOUTEAU, F., LEUNG, J. 2014. Acetylated 1,3-diaminopropane antagonizes abscisic acid-mediated stomatal closing in Arabidopsis. The Plant Journal, 79(2), 322-333. https://doi.org/10.1111/tpj.12564

JONES, P.A., BROSNAN, J.T., KOPSELL, D.A., ARMEL, G.R., BREEDEN, G.K. 2013. Preemergence herbicides affect hybrid bermudagrass nutrient content. Journal of Plant Nutrition, 38(2), 177-188 https://doi.org/10.1080/01904167.2013.837179.

KAKEHI, J.I., KUWASHIRO, Y., NIITSU, M., TAKAHASHI, T. 2008. Thermospermine is required for stem elongation in Arabidopsis thaliana. Plant and Cell Physiology, 49(9), 1342-1349. https://doi.org/10.1093/pcp/pcn109. KAYA-ALTOP E., HAGHNAMA K., SARIASLAN D., PHILLIPPO C. J. MENNAN H., ZANDSTRA B. H. 2016. Long-term perennial weed control strategies: economic analyses and yield effect in hazelnut (Corylus avellana) Crop Protection, 80, 7-14. https://doi.org/10.1016/j.cropro.2015.10.022.

KIM, H.S., JIN, C.D. 2006. Polyamines as antioxidant protectors against paraquat damage in radish Raphanus sativus L. cotyledons. Journal of Plant Biology, 49(3), 237-246. https://doi.org/10.1007/bf03030539.

KNOTT, J.M., RÖMER, P., SUMPER, M. 2007. Putative spermine synthases from Thalassiosira pseudonana and Arabidopsis thaliana synthesize thermospermine rather than spermine. FEBS Letters, 581(16), 3081- 3086 https://doi.org/10.1016/j.febslet.2007.05.074.

KORTEKAMP, A. 2011. Unexpected side effects of herbicides: modulation of plant-pathogen interactions. Herbicides and Environment, 85-104, InTech Rijeka, 746 p. ISBN 978-953-307-476-4. https://doi.org/10.5772/13217.

LIU, T., KIM, D.W., NIITSU, M., MAEDA, S., WATANABE, M., KAMIO, Y., BERBERICH, T., KUSANO, T. 2014. Polyamine oxidase 7 is a terminal catabolism-type enzyme in Oryza sativa and is Specifically expressed in anthers. Plant and Cell Physiology, 55(6), 1110-1122. https://doi.org/10.1093/pcp/pcu047.

MATTOO, A.K., MINOCHA, S.C., MINOCHA, R., HANDA, A.K. 2010 Polyamines and cellular metabolism in plants: transgenic approaches reveal different responses to diamine putrescine versus higher polyamines spermidine and spermine. Amino Acids, 38(2), 405-413. https://doi.org/10.1007/s00726-0090399-4.

MONTILlA-BASCÓN, G., RUBIALES, D., ALTABELlA, T., PRATS, E. 2016. Free polyamine and polyamine regulation during pre-penetration and penetration resistance events in oat against crown rust (Puccinia coronata f. $s p$. avenae). Plant Pathology, 65(3), 392-401. https://doi.org/10.1111/ppa.12423.

NIKMARAN, N., DAR, B., ROOHINEJAD, S., KOUBAA, M., BARBA, F.J., GREINER, R., JOHNSON, S.K. 2017. Recent advances in $\gamma$-aminobutyric acid (GABA) properties in pulses: an overview. Journal of the Science of Food and Agriculture, 97(9), 2681-2689. https://doi.org/10.1002/jsfa.8283.

POOJARY, M.M., DELlAROSA, N., ROOHINEJAD, S., KOUBAA, M., TYLEWICZ, U., GÓMEZ-GALINDO, F., SARAIVA, J.A., ROSA, M.D., BARBA, F.J. 2017. Influence of Innovative Processing on $\gamma$-Aminobutyric Acid (GABA) Contents in Plant Food Materials. Comprehensive Reviews in Food Science and Food Safety, 16(5), 895-905 https://doi.org/10.1111/15414337.12285

SANDÍN-ESPAÑA, P., LOUREIRO, I., ESCORIAL C., CHUECA, C., SANTÍN-MONTANYÁ, I. 2011. The bioassay technique in the study of the herbicide effects. Herbicides, Theory and Applications, 431-454 https://doi.org/10.5772/13571

SÁNCHEZ-LÓPEZ, Á.M., BAHAJI, A., De DIEGO, N., BASLAM, M., MUÑOZ, F.J., ALMAGRO, G., GARCÍA-GÓMEZ, P., AMEZTOY, K., RICARTE-BERMEJO, A., NOVÁK, O., HUMPLÍK J.F., SPÍCHAL, L. DOLEŽAL, K., CIORDIA, S., MENA, M.C., NAVAJAS, R., BAROJAFERNÁNDEZ, E., POZUETA-ROMERO, J. 2016. Arabidopsis responds to Alternaria alternata volatiles by triggering plastid phosphoglucose isomeraseindependent mechanisms. Plant Physiology, 172(3), 1989-2001. https://doi.org/10.1104/pp.16.00945.

SOLTANI N., DILLE A. J., BURKE I. C., EVERMAN W. J., VANGESSEL M J., DAVIS V. M. 2016. Potential corn yield losses due to weeds in North America. Weed Technology. 30(4), 979-984. https://doi.org/10.1614/wt-d-1600046.1 .

TAKAHASHI, T., KAKEHI, J.-I. 2010. Polyamines: ubiquitous polycations with unique roles in growth and stress responses. Annals of Botany, 105(1), https://doi.org/10.1093/aob/mcp259.

TIBURCIO, A.F., ALTABELLA, T., BITRIAN, M., ALCAZAR, R. 2014. The roles of polyamines during the lifespan of plants: from development to stress. Planta, 240(1), 1-18. https://doi.org/10.1007/s00425-014-2055-9

TODOROVA, D., KATEROVA, Z., SERGIEV, I., ALEXIEVA, V. 2013. Role of polyamines in alleviating salt stress. Soil and water management for sustained agriculture in alluvial plains and flood pains exposed to salinity: a case of neretva river valley. Springer, Editors, P.Ahmad et al.: New York, first edition, 355-379. https://doi.org/10.1007/978-1-4614-4747-4 13

TODOROVA, D., SERGIEV, I., ALEXIEVA, V. 2012. Application of natural and synthetic polyamines as growth regulators to improve the freezing tolerance of winter wheat (Triticum aestivum L.). Acta Agronomica Hungarica, 60(1), 1 10. https://doi.org/10.1556/aagr.60.2012.1.1.

TOMKA M., URMINSKÁ, D., CHŇAPEK, M., GÁLOVÁ, Z. 2017. Potential of selected SSR markers for identification of malting barley genotypes. Journal of Microbiology, Biotechnology and Food Sciences, 6(6), 1276-1279. https://doi.org/10.15414/jmbfs.2017.6.6.1276-1279.

TREBST, A. 2008. The mode of action of triazine herbicides. The triazine herbicides: 50 years revolutionizing agriculture, LeBaron, H.M., McFarland, J.E \& Burnside, O. (Eds.), 101-110. Elsevier : Oxford (UK). ISBN 978-0-444-511676. https://doi.org/10.1016/b978-044451167-6.50011-8

VARSHNEY, S., IQBAL, M.R.K., MASOOD, A., TASIR, S.P., RASHEED, F., NAFEES, A.K. 2015. Contribution of Plant Growth Regulators in Mitigation of Herbicidal Stress. Journal of Plant Biochemistry \& Physiology, 3(4), 1-10. https://doi.org/10.4172/2329-9029.1000160.

VELINI, E.D., TRINDADE, M.L.B., BARBERIS, L.R.M., DUKE, S.O. 2010 Growth Regulation and Other Secondary Effects of Herbicides. Weed Science 58(3), 351-354. https://doi.org/10.1614/ws-d-09-00028.1. 